\title{
Analisis Mutu Air Tanah Tempat Pembuangan Akhir (TPA) (Studi Kasus TPA Sampah Sukawinatan Palembang)
}

\author{
Pra Dian Mariadi ${ }^{1 *}$, Ian Kurniawan ${ }^{2}$ \\ *e-mail: pradian@ukmc.ac.id \\ 1,2 Program Studi Diploma IV Teknologi Laboratorium Medik \\ Universitas Katolik Musi Charitas
}

\begin{abstract}
The Palembang city still has several locations for Final Disposal Sites, one of which is located in Sukarame District. Sukawinatan landfill began operations in 1994 with a land area of 25 hectares and has been used 15 hectares, the remaining 10 hectares of land is estimated to be able to accommodate waste until 2028. In some part, groundwater is still used for daily life originating from ground water, especially in RT 68, which is used for domestic needs such as bathing, brushing teeth, washing clothes, washing utensils, and cooking. The results showed that based on the physical parameters it was concluded that 5 odor samples fulfilled the requirements, 5 taste samples fulfilled the requirements, 4 samples of dissolved solids met the requirements, 3 turbidity samples fulfilled the requirements, and 5 temperature and color samples met the requirements. Based on the chemical parameters it was concluded that the fivesamples did not exceed the maximum permissible levels except for $\mathrm{pH}$ parameters. Based on organic chemical parameters it is concluded that all samples meet the criteriaof organic chemistry. The water quality index of all well samples is very good.
\end{abstract}

Keywords: Final Disposal Sites, Sukawinatan, Water Quality index

\begin{abstract}
ABSTRAK
Kota Palembang masih memiliki beberapa lokasi Tempat Pembuangan Akhir sampah, yaitu yang berlokasi di Kecamatan Sukarame. TPA Sukawinatan sudahberoperasimulai tahun 1994 dan luas lahan 25 hektar sertatelah terpakai 15 hektar, sisa lahan 10 hektar diperkirakan dapat mengolah dan menampung sampah hingga tahun 2028. Di beberapa RT yang berdekatan dengan pusat TPA Sukawinatan masih menggunakan air tanah untuk kehidupan sehari hari yang berasal dari air tanah terutama di RT 68 yang dipergunakan untuk keperluan domestik rumah tangga seperti mandi, menyikat gigi, mencuci pakaian, mencuci alat-alat makan, memasak dan sebagainya. Hasilpenelitian menunjukkan bahwa Berdasarkan parameter fisika disimpulkan bahwa 5 sampel bau memenuhi syarat, 5 sampel rasa memenuhi syarat, 4 sampel jumlah padatan terlarut memenuhi syarat, 3 sampel Kekeruhan memenuhi syarat, dan 5 sampel suhu dan warna memenuhi syarat.Berdasarkan parameter kimia disimpulkan bahwa kelima sampel tidak ada yang melebihi batas maksimal kadar yang diizinkan kecuali untuk parameter $\mathrm{pH}$. Berdsarkan parameter kimia organik disimpulkan bahwa semua sampel memenuhi kriteria kimia organik. Water quality indeks semua sampel sumur kondisnya sangat baik
\end{abstract}

Kata Kunci: Tempat pembuangan akhir, Sukawinatan, Indeks Kualitas Air

\section{PENDAHULUAN}

Air adalah bahan kimia yang sangat penting untuk semua mahluk hidup terutama bagi manusia. Untuk kelangsungan hidup dan manfaatnya 
untuk kehidupan tidak dapat digantikan dengan senyawa lain. (Udhayakumar, Manivannan, Raghu, Vaideki,2016). Air di perkotaan dapat mengalami pencemaran dikarenakan berbagai limbah seperti air limbah, limbah rumah tangga, limbah gas, dan limbah panas (Bahagia, Yunita, I., Ruslin, 2018). ). Air tanah saat ini masih jadi sumber air untuk keperluan berbagai kegiatan rumah tangga. Air tanah rentan terhadap pencemaran yang berasal dari penggunaan pestisida, pupuk dan sampah (Ignatius, Thara, \&Dheenadayalan,2018).

Air tanah yang berdekatan dengan tempat pembuangan akhir (TPA) sampah dihadapkan dengan berbagai masalah. Permasalahan tersebut meliputi tingginya laju timbunan sampah dan menurunnya kualitas lingkungan (Indah, Zulkifli, Faisal, 2006). Sampah yang menggunung akan menghasilkan lindi cair yang merupakan hasil dekomposisi sampahdan pengaruh luar (Yudhyarto,Utomo,\& Sulastro, 2015). Pengaruh lindi yang mencemari air tanah dan sumber air lainnya menjadi perhatian karena dampaknya yang luar biasa terhadap penurunan kualitas air. Lindi yang berpindah dari tempat pembuangan akhir sampah melepaskan zat pencemar yang sangat berbahaya bagi kesehatan (Ikem, Osibanju, Sidhan, \& Sobande, 2002).

Lindi yang berasaldari pembuangan sampah mengandung dua bahan yaitu bahan organik dan anorganik terlarut yang menjadi zat pencemar seperti amonium, kalsium, sodium, potasium, besi, sulfat, klorida dan logam berat seperti $\mathrm{Cd}, \mathrm{Cr}, \mathrm{Co}, \mathrm{Pb}, \mathrm{Zn}$ dan $\mathrm{Ni}$ (Aboyeji\& Eigbkhan, 2016). Logam berat yang mencemari air tanah dapat mengganggu kesehatan apabila terkonsumsi karena sifatnya yang dapat terakumulasi dalam tubuh dan menjadi pemicu kanker (Chwodhury, Mazumder, , Al Attas, \&Husain,2016).

Menurut penelitian Sari dan Munawar (2015) menyatakan terhadap hubungan yang sangat kuat antara jarak timbunan sampah dan air lindi terhadap kualitas air untuk parameter total coliform, Chemical oxygen Demand (COD), Total Suspended Solid (TSS) dan Demand Oxygen (DO). Menurut Arbain,Mardana, Sudana, (2012), air lindi berpengaruh pada kualitas air tanah dangkal penduduk yang berdekatan dengan TPA. Menurut Biswas et al (2010) menyatakan air lindi yang tercemar akan meningkatkan pencemaran logam berat pada air tanah.

Kota Palembang masih memiliki beberapa lokasi Tempat Pembuangan Akhir sampah, yaitu yang berlokasi di Kecamatan Sukarame. TPA Sukawinatan sudah beroperasi mulai tahun 1994 dan luas lahan 25 hektar sertatelah terpakai 15 hektar, sisa lahan 10 hektar diperkirakan dapat mengolah dan menampung sampah hingga tahun 2028 (Warsinah, Suheryanto \& Windusari, 2015). TPA Sukawinatan berjarak $10 \mathrm{~km}$ dari pusat kota dan telah menggunakan sistem kontrol landfill. Jumlah penduduk disekitar TPA Sukawinatan berjumlah lebih dari $950 \mathrm{KK}$ dan terdapat 5 (lima) RT yaitu RT 68, 62, 36, 75 dan RT.91. Padatnya jumlah penduduk di sekitar TPA Sukawinatan yang berjumlah \pm 4.780 jiwa dan dibeberapa RT masih menggunakan air untuk kehidupan sehari hari yang berasal dari air tanah terutama di RT 68 .

Lindi adalah sumber pencemaran air yang dapat berupa material organik dan material anorganik yang berasal dari pembusukan sampah di sebuah tempat pembuangan akhir (TPA) sampah. Zat polutan tersebut dapat menurunkan kualitas air baik dari kualitas fisika, kimia dan biologi (Ali, 2011). Lindi juga menjadi sumber pencemaran logam berat dalam air tanah sehingga diperlukan penilaian kualitas air tanah di RT 68 yang berbatasan langsung dengan TPA Sukawinatan. Kualitas air tanah yang diteliti berupa kualitas fisika dan kimia. 


\section{BAHAN DAN METODE}

Jenis penelitian yang digunakan pada riset ini adalah penelitian observasional analitik yang menggunakan rancangan cross sectional yang dilakukan pada bulan November 2018 - Januari 2019. Populasi yang digunakan dalam penelitian ini adalah semua sumur gali yang berdekatan dengan TPA Sukawinatan yaitu di RT 68 Kelurahan Sukarame, Kecamatan Sukarame Palembang. Cara pengambilan sampel air sumur warga RT 68 menggunakan metode purposive sampling yaitu dengan kriteria sumur warga yang masih dipergunakan untuk kebutuhan air bersih,dan untuk beberapa keperluan domestik rumah tangga umumnya mulai dari mencuci baju, mencuci peralatan makan, mandi, memasak dan kegiatan lainnya.

Metode pengambilan sampel penelitian ini yang berupa sampel air tanah di RT 68 dilakukan secara langsung mengunakan metode grab sampling yaitu metode pengambilan sampel air warga sesaat yang telah menunjukkan karakteristik air hanya pada saat pengambilan sampel mengunakan alat pengambil sampel air berupa water sampler sesuai dengan SNI 6989.59:2008. Sebelum dianalisa di laboratorium analisa air dilakukan perlakuan pre analitik sampel berupa pengawetan yang bertujuan agartidak terjadi perubahan kimia dan fisika pada sampel air. Parameter yang dianalisis dari sampel air meliputi parameter fisika dan kimia Menurut survey pendahuluan, jumlah sampel sumur di RT 68 berjumlah 12 sumur dan layak untuk diambil air nya terdiri dari 5 sumur.

Beberapa metode pemeriksaan fisika dan kimia yang digunakan antara lain untuk Kekeruhan dilakukan dengan metode SNI 06-6989.25-2005. Untuk pengujian suhu air di lapangan menggunakan metode SNI 06-
6989.23.23-2005.Kelima sampel diuji dengan metode SNI 06-6989.29-2004 untuk analisa flourida

Analisis data yang digunakan adalah analisis menggunakan Water Quality Index yang memiliki lima tingkatan kualitas yaitu sangat baik, baik, buruk, sangat buruk dan air tiadak cocok untuk dikonsumsi. Water Quality Index dihitung berdasarkan standar dari World Health Organization (Brown, Clelland, Dininger \&Tozer, 1970) secaraaritmatika sesuai rumusan dibawah ini

$$
\mathrm{Q}_{\mathrm{n}}=100[(\mathrm{Vn}-\mathrm{Vi} /(\mathrm{Sn}-\mathrm{Vi})] \ldots(1)
$$

Dimana :

Qn = Water Quality Rating tiap parameter

$\mathrm{Vn}=$ Nilai hasil pemeriksaan'

$\mathrm{Sn}=$ Batas maksimal kadar yang diizinkan tiap parameter

$\mathrm{Vi}=$ Nilai ideal tiap parameter

Perhitungan berat tiap unit (Wn)

$$
\mathrm{Wn}=\mathrm{K} / \mathrm{Sn} . .(2)
$$

Dimana

$\mathrm{Wn}=$ unit berat tiap parameter

Sn = Batas maksimal kadar yang diizinkan tiap parameter

$\mathrm{K}=$ Konstanta proporsional

Konstanta proporsional dihitung menggunakan rumus

$$
\mathrm{K}=1 / \Sigma(1 / \mathrm{Sn})
$$

Perhitungan Water Quality Indeks(WQI) dihitung menggunakan rumus

$$
\mathrm{WQI}=\Sigma \mathrm{Qn} . \mathrm{Wn} / \Sigma \mathrm{Wn}
$$

\section{HASIL DAN PEMBAHASAN}

Sampel penelitian ini adalah 5 sumur warga yang masih digunakan untuk kebutuhan sehari-hari di RT 68 kelurahan Sukarame dan tidak berdinding 
beton yang akan dianalisis secara Fisika dan Kimia

\section{Parameter Fisika}

Berdasarkan hasil penelitian air sumur di RT 68 dapat dilihat bahwa 5 sampel air sumur yang diperiksa karakteristik bau memenuhi syarat, 5 sampel air sumur yang diperiksa karakteristik rasa memenuhi syarat, 4 sampel air sumur yang diperiksa karakteristik jumlah padatan terlarut memenuhi syarat, 3 sampel air sumur yang diperiksa karakteristik kekeruhan memenuhi syarat, dan 5 sampel air sumur yang diperiksa karakteristik suhu dan warna memenuhi syarat. Hasil lengkap pemeriksaan parameter fisika yang diujikam di Balai Teknik Kesehatan Lingkungan dan Pengendalian Penyakit (BTKLPP) Palembang dapat dilihat pada tabel 1 dibawah ini.

Tabel 1. Hasil Analisis Fisika Air

\begin{tabular}{|c|c|c|c|c|c|c|c|}
\hline \multirow{2}{*}{$\begin{array}{l}\text { Parameter } \\
\text { Fisika }\end{array}$} & \multirow[t]{2}{*}{ Satuan } & \multirow{2}{*}{$\begin{array}{l}\text { Batas } \\
\text { maksimum } \\
\text { yang } \\
\text { diperbolehkan* }\end{array}$} & \multicolumn{5}{|c|}{ Hasil Sampel } \\
\hline & & & A & B & $\mathrm{C}$ & $\mathrm{D}$ & $\mathrm{E}$ \\
\hline 1. Bau & $\#$ & Tidak berbau & $\begin{array}{l}\text { Tidak } \\
\text { berbau }\end{array}$ & $\begin{array}{l}\text { Tidak } \\
\text { berbau }\end{array}$ & $\begin{array}{l}\text { Tidak } \\
\text { berbau }\end{array}$ & $\begin{array}{l}\text { Tidak } \\
\text { berbau }\end{array}$ & $\begin{array}{l}\text { Tidak } \\
\text { berbau }\end{array}$ \\
\hline 2. Rasa & $\#$ & Tidak berasa & $\begin{array}{l}\text { Tidak } \\
\text { berasa }\end{array}$ & $\begin{array}{l}\text { Tidak } \\
\text { berasa }\end{array}$ & $\begin{array}{l}\text { Tidak } \\
\text { berasa }\end{array}$ & $\begin{array}{l}\text { Tidak } \\
\text { berasa }\end{array}$ & $\begin{array}{l}\text { Tidak } \\
\text { berasa }\end{array}$ \\
\hline $\begin{array}{l}\text { 3. Jumlah } \\
\text { padatan } \\
\text { terlarut }\end{array}$ & $\mathrm{mg} / \mathrm{liter}$ & 500 & 360 & 229 & 547 & 148 & 294 \\
\hline 4. Kekeruhan & NTU & 5 & 20.31 & 2.95 & 41.50 & 4.43 & 3.20 \\
\hline 5. Suhu & ${ }^{\circ} \mathrm{C}$ & Suhu Udara \pm 3 & 25.9 & 25.9 & 25.8 & 25.8 & 25.9 \\
\hline 6. Warna & TCU & 15 & 6 & 6 & 7 & 7 & 7 \\
\hline
\end{tabular}

Air yang sesuai persyaratan kualitas fisik adalah air yang tidak berbau, berwarna, berasa, tidak keruh dan memiliki suhu air dibawah suhu udara sekitarnya. Pengujian bau dan rasa dilakukan menggunakan metode Organoleptik. Hasil penelitian menunjukkan bahwa semua sampel air yang digunakan dalam penelitian ini tidak berasa dan tidak berbau sehingga sesuai dengan persyaratan maksimum yang diperbolehkan sesuai dengan Permenkes No 492/Menkes/Per/IV/2010 mengenai persyaratan mutu air minum dan air bersih.

Air sumur yang berbau umumnya disebabkan adanya materi organik yang mengalami pembusukan (Trisnawulan, Budiarsa \& Sundra, 2007). Air yang bau dan berasa biasanya terjadi bersamaan dandiakibatkan oleh adanya proses pembusukan dan dekomposisi bahan-bahan organik, beberapa organisme mikrokopik serta persenyawaan kimiaseperti phenol. Menurut Slamet (2005), bau dalam air yang digunakan berasal dari adanya mikroorganisme dalam air seperti alga serta adanya gas lain seperti asam sulfida $\left(\mathrm{H}_{2} \mathrm{~S}\right)$ yang terbentukdibawah system anaerobik dan adanya senyawa-senyawa organik lainnya.

Untuk kekeruhan dari kelima sampel, terdapat dua sampel yang memiliki nilai kekeruhan diatas ambang batas yaitu sebesar 41.50 NTU dan 20,31 NTU serta kadar terendah sebesar 2.95 NTU. Rata-rata hasil pengukuran kekeruhan sebesar 14.5 NTU.

Kekeruhan pada air disebabkan oleh adanya bahan padat tersuspensi, baik organik maupun anorganik. Berbagai buangan limbah domestik, pertanian dan industri merupakan sumber kekeruhan (Gofur, Kartini \& Rhaman, 2016). Menurut penelitian Parera, Wenny \& 
Jimmy (2012), sumur gali warga memiliki lapisan tanah yang berdekatan dengan tanah permukaan sehingga lebih rentan terhadap kontaminasi yang berasal dari limbah oleh kegiatan manusia dankegiatan industry yang masuk melalu rembesan permukaan.

Dari tabel di atas, ditunjukkan bahwa temperatur air sumur tertinggi yaitu $25.9{ }^{\circ} \mathrm{C}$ dan terendah $25.9{ }^{\circ} \mathrm{C}$. Temperatur air sumur adalah salah satu parameter penting yang erat hubungannya dengan pengolahan yang bertujuan untuk eliminasi bahan bahan pencemar dan tujuan penggunaan air (Suripin, 2001). Temperatur air yangdiinginkan adalah \pm $3^{0} \mathrm{C}$ suhu udara di sekitarnya. Temperatur air mempengaruhi langsung kualitas air lainnya seperti toksisitas berupa tingginya bahan kimia pencemar, pertumbuhan dan perkembangan mikroorganisme dan virus (Suryana, 2013). Tinggi rendahnya temperatur air dalam suatu sistem penampungan dipengaruhi oleh beberapa faktor seperti proses fisik dalam air dan keadaan atmosfir sekitarnya (Marwati, 2008).

Untuk pengujian warna dari kelima sampel tersebut memiliki kadar rata-rata 6.6 TCU dengan kadar tertinggi 7 TCU dan terendah 6 TCU. Hasil pemeriksaan fisik berupa warna menunjukkan bahwa semua sampel air sumur warga RT 68 yang digunakan dalam peneltian ini tidak berwarna.Hal ini kemungkinan menunjukkan bahwa dalam sampel air sumur warga tersebut tidak mengandung mikrorganisme, bahan kimia tersuspensi dan ekstrak senyawaan organik serta tumbuh-tumbuhan yang mengakibatkan warna dalam air. Menurut Abdul, Yusuf \& Prasetya (2014), kondisi sumur warga yang dibuat tidak permanen serta tidak dibuat memiliki dinding dan lantai sumur menyebabkan limbah yang berasal dari kegiatan rumah tangga, air hujan dan air laut lebih mudah merembes dan meresap kedalam air sumur sehingga mengganggu kualitan kejernihan airsumur warga. Menurut Gusnisar (2012), warna dalam air sumur juga dapat disebabkan oleh organisme, bahan persenyawaan kimia berwarna yangtersuspensi, ekstrak senyawaan organik dan tumbuhan .

Untuk pengujian jumlah zat padat terlarut didapatkan hasil tertinggi 547 $\mathrm{mg} / \mathrm{liter}$ dan kadar terendah sebesar 148 mg/liter dengan rata-rata kadar sebesar $316 \mathrm{mg} /$ Liter. Total zat terlarut menunjukkan banyaknya partikel bahan padat yang terdapat dalam air sumur. Senyawaan padat ini berasal dari bahan organik dan anorganik yang terlarut dalam air, senyawaan mineral dan senyawaan garam. Padatan terlarut dalam air akan mempengaruhi kesehatan dan kulitas air berupa rasa air yang tidak enak, rasa mual setelah konsumsi yang diakibatkan bahan kimia berupa natrium dan magnesium sulfat (Mukti, 2008).

Hasil pengujian padatan terlarut (TDS) ini menunjukkan ada satu sampel air sumur yang melampaui batas padatan zat terlarut. Hal ini menunjukkan bahwa dalam satu sampel tersebut mengandung padatan tersuspensi, lumpur dan material tanag liat serta zat anorganik lainya yang meningkatkan kekeruhan air. Menurut Gusnisar (2012), sumur yang lebih dangkal memiliki TDS yang relative lebih tinggi dikarenakan sumur yang lebih dangkal lebih rentan kontaminasi yang berasal dari bahan pencemar darikegiatan manusia merembes ke air sumur dangkalsedangkan menurut Ugya, Umar \& Yusuf (2015), tingginya kadar TDS dalam air sumur di daerah industri dapat disebabkan oleh kegiatan industri yang melepasakan banyak bahan kimia yang memicu meningkatnya turbidity di dalam penampungan air dan air sumur.

\section{Parameter Kimia}

Parameter kimia yang diujikan terhadap 5 sampel air sumur berupa pengujian kadar Besi (Fe), Flourida (F), 
Kadmium (Cd), Kesadahan $\left(\mathrm{CaCO}_{3}\right)$, Mangan (Mn), Nitrat sebagai $\mathrm{N}\left(\mathrm{NO}_{3}\right)$, Nitrit sebagai $\mathrm{N}\left(\mathrm{NO}_{2}\right)$, $\mathrm{pH}$, Seng $(\mathrm{Zn})$, Sianida $(\mathrm{CN})$, Sulfat $\left(\mathrm{SO}_{4}\right)$ dan logam timbal $(\mathrm{Pb})$. Hasil pengujian lengkap lima sampel yang diujikan di laboratorium
Balai Teknik Kesehatan Lingkungan dan Pengendalian Penyakit (BTKLPP) Palembang dapat dilihat pada tabel 2 dibawah ini.

Tabel 2. Hasil Analisis Kimia Air

\begin{tabular}{|c|c|c|c|c|c|c|c|}
\hline \multirow[b]{2}{*}{$\begin{array}{l}\text { Parameter } \\
\text { Kimia }\end{array}$} & \multirow[b]{2}{*}{ Satuan } & \multirow{2}{*}{$\begin{array}{c}\text { Batas } \\
\text { maksimum } \\
\text { yang } \\
\text { diperbolehkan* }\end{array}$} & \multicolumn{5}{|c|}{ Hasil Sampel } \\
\hline & & & A & B & $\mathrm{C}$ & D & $\mathrm{E}$ \\
\hline 1. $\quad$ Besi $(\mathrm{Fe})$ & $\mathrm{mg} / \mathrm{L}$ & 0,3 & 0,14 & 0,09 & 0,06 & 0,12 & 0,08 \\
\hline $\begin{array}{ll}\text { 2. } & \text { Flourida } \\
(\mathrm{F})\end{array}$ & $\mathrm{mg} / \mathrm{L}$ & 1,5 & 0,08 & 0,09 & 0,08 & 0,09 & 0,09 \\
\hline $\begin{array}{l}\text { 3. Kadmium } \\
(\mathrm{Cd})\end{array}$ & $\mathrm{mg} / \mathrm{L}$ & 0,003 & $<0,0015$ & $<0,0015$ & $<0,0015$ & $<0,0015$ & $<0,0015$ \\
\hline $\begin{array}{l}\text { 4. Kesadahan } \\
\left(\mathrm{CaCO}_{3}\right)\end{array}$ & $\mathrm{mg} / \mathrm{L}$ & 500 & 172,2 & 161,7 & 180,6 & 159,6 & 157,5 \\
\hline $\begin{array}{l}\text { 5. Mangan } \\
(\mathrm{Mn})\end{array}$ & $\mathrm{mg} / \mathrm{L}$ & 0,4 & 0,03 & $<0,0033$ & $<0,0033$ & 0,04 & $<0,0033$ \\
\hline $\begin{array}{l}\text { 6. } \begin{array}{l}\text { Nitrat } \\
\text { sebagai } \mathrm{N}\end{array} \\
\end{array}$ & $\mathrm{mg} / \mathrm{L}$ & 50 & 9,2 & 9,3 & 21,5 & 13,7 & 18 \\
\hline $\begin{array}{l}\text { 7. Nitrit } \\
\text { sebagai N }\end{array}$ & $\mathrm{mg} / \mathrm{L}$ & 3 & 0,015 & 0,045 & 2,95 & 0,019 & 0,015 \\
\hline 8. $\mathrm{pH}$ & \# & $6,5-8,5$ & 6,25 & 5,26 & 6,46 & 5,14 & 4,24 \\
\hline 9. Seng $(\mathrm{Zn})$ & $\mathrm{mg} / \mathrm{L}$ & 3 & 0,07 & $<0,005$ & 0,04 & 0,130 & $<0,005$ \\
\hline $\begin{array}{l}\text { 10. Sianida } \\
(\mathrm{CN})\end{array}$ & $\mathrm{mg} / \mathrm{L}$ & 0,07 & 0,003 & 0,004 & 0,006 & 0,004 & 0,006 \\
\hline 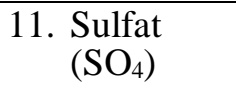 & $\mathrm{mg} / \mathrm{L}$ & 250 & 14,96 & 5,83 & 0,97 & 0,86 & 0,63 \\
\hline $\begin{array}{l}\text { 12. Timbal } \\
(\mathrm{Pb})\end{array}$ & $\mathrm{mg} / \mathrm{L}$ & 0,05 & $<0,0031$ & $<0,031$ & $<0,0031$ & 0,01 & $<0,0031$ \\
\hline
\end{tabular}

Besi merupakan unsur kimia yang ditemukan pada hampir semua tempat di bumi dan menjadi salah satu logam berat berbahaya jika konsenrasinya melewati ambang batas (Soemirat, 2009). Darihasil penelitian, kelima sumur yang dijadikan sampel penelitian menunjukkantidak ada sampel yang melebihi ambang batas kadar besi dalam air bersih dengan nilai tertinggi $0,14 \mathrm{mg} / \mathrm{L}$ dan terendah $0,06 \mathrm{mg} / \mathrm{L}$. Menurut Soemirat (2009), besidapat larut pada $\mathrm{pH}$ rendah. Kadarnya dalam air bersih tidak boleh melebihi $0,3 \mathrm{mg} / \mathrm{L}$ karena menyebabkan dan meningkatkan bau, rasa serta mengakibatkan air sumur akan berwarna dan meningkatkan potensi meninggalkan noda pada pakaian jika digunakan dan menyebabkan iritasi mata dan kulit

Pada pemeriksaan parameter kimia salah satunya adalah pemeriksaan kadar flourida/flouride dalam air bersih. Kelima sampel yang diuji menunjukkan bahwa semuasampel memenuhi syarat kadar flourida. Menurut Widana et al (2014), adanya flourida berasal dari dekomposisi persenyawaan flourida yang secara alami sudah terdapat dalam tanah.

Derajat keasamanan adalah parameter yang menunjukkan sifat keasaman dan kebasaan dalam suatu sampel. Perubahan derajat keasaman 
dalam suatu sistem penampungan air dan perairan akan mempengaruhi berbagai proses fisika, kimia dan biologi mikroorganisme yang terdapat dalam sistem peraiaran tersebut. Derajat keasaman juga dapat mempengaruhi toksisitas bahan pencemaran dalam air dan kelarutan gas serta menentukan bentuk zat (Wardhana, 2004). Hasil penelitian ini menunjukkan bahwa kelimasampel air sumur di RT 68 tidak memenuhi syarat untuk parameter $\mathrm{pH}$ air bersih

Air yang memiliki keasaman yang tinggi diakibatkan meningkatnya kadar nitrit dan nitrat yang larut dan masuk kedalam air tanah seperti air sumur dimana nitrat dan nitrat ini berubah menjadi polutan bagi air sumur (Nayyef and Amal, 2012; Ugya et al, 2015). Jika $\mathrm{pH}$ air dibawah 6,5 artinya air tersebut bersifat asam sehingga air ini kurang baik bagi tubuh kita jika dikonsumsi karena jika $\mathrm{pH}$ asam akan mempengaruhi sistem pencernaan, mudah lelah, mengakibatkan rasa sakit persendian (Narsi, Wahyuni\&Susanti 2017). pH air yang asam dapat merusak kondisi kulit dan menyebabkan iritasi (Roger, 2010), korosi pada metal (pipa air) yang melarutkan logam berat seperti timbal $(\mathrm{Pb})$, tembaga $(\mathrm{Cu})$ dan cadmium $(\mathrm{Cd})$ (Sudadi, 2003).

Hasil pemeriksaan Nitrit sebagai $\mathrm{N}\left(\mathrm{NO}_{2}\right)$ dan nitrat sebagai $\mathrm{N}\left(\mathrm{NO}_{3}\right)$ menunjukkan kelima sampel memenuhi syarat kualitas kadar nitrit dan nitrat sesuai Permenkes No

492/Menkes/Per/IV/2010 tentang kualitas air bersih. Namun jika mengacu Permenkes no 32 tahun 2017 tentang persyaratan baku mutu kesehatan lingkungan dan persyaratan kesehatan air yang digunakan untuk keperluan higiene sanitasi terdapat 3 sampel air sumur warga RT 68 yang tidak sesuai baku mutu kadar nitrat yaitu sampel C, D dan

E. Tingginya kadar Nitrit dan Nitrat dalam air disebabkan oleh adanya penggunaan pupuk yang berlebihan dimana pupuk merupakan sumber utama Nitrogen yang dikonversi dari nitrit dan nitrat (Nas, 2009; Eddy dan Ekop, 2007). Tingginya senyawa nitrat dalam iar yang akan dikonsumsi dapat menyebabkan kondisi methamoglobinemia yaitu kondisi berubahnya Hemoglobin dlam darah menjadi methamoglobin yang akan menyebkan kandungan oksigen darah menjadi rendah dan dikenal dengan penyakit "babie blues" (Soemirat, 2009)

Logam berat dalam air bersih dan air minum yang menjadi racun bagi tubuh manusia adalah Timbal $(\mathrm{Pb})$, Besi $(\mathrm{Fe})$, Kadmium (Cd), Seng (Zn) dan Mangan (Mn). Hasil penelitian menunjukan kelima logam dalam lima sampel air sumur yang digunanakan dalam penelitin ini tidak ada yang melebihi ambang batas maksimal logam dalam air bersih. Untuk batas maksimal logam besi dalam air adalah $0,3 \mathrm{mg} /$ Liter. Logam yang toksik bagi manusia biasanya didapatkan dari kegiatan industri, limbah domestik dan tumpukan sampah dapat menjadi berbahaya bagi manusia dan lingkungan biotik.Logam berat yang diukur dalam penelitian ini adalah logam timbal $(\mathrm{Pb})$, Cadmium (Cd), Seng (Zn) dan Mangan $(\mathrm{Mn})$. Kandungan logam besi tertinggi dalam sampel adalah $0,14 \mathrm{mg} / \mathrm{L}$ dengan batas tertinggidalam air sebesar $0,3 \mathrm{mg} / \mathrm{L}$. Untuk logam kadmium $(\mathrm{Cd})$ kandungan tertinggi $<0,0015 \mathrm{mg} / \mathrm{L}$ dengan batas maksimal 0,003 mg/L. Kandungan logam Mangan tertinggi sebesar $0,04 \mathrm{mg} / \mathrm{L}$ dengan batas maksimal yang diizinkan sebesar $0,4 \mathrm{mg} / \mathrm{L}$. Kandungan tertinggi logam seng $(\mathrm{Zn})$ dan Timbal $(\mathrm{Pb})$ tertinggi berturut-turut $0,13 \mathrm{mg} / \mathrm{L}$ dan $0,01 \mathrm{mg} / \mathrm{L}$ dengan batas maksimal yang diizinkan sebesar $3 \mathrm{mg} / \mathrm{L}$ untuk logam seng dan0,05 $\mathrm{mg} / \mathrm{L}$ untuk logam timbal.

Kandungan logam logam berat dalam air ini relatif sangat kecil, akan tetapi hal ini tetap harus diwaspadai mengingat efek toksikologi bagi tubuh dan sifatnya yang dapat terakumulasi 
dalam tubuh. Logam kadmium dalam tubuh selang waktu yang lama dapat mengakibatkan kerusakan ginjal. Logam timbal dapat menyebabkan gangguan sistem syaraf, menyebabkan pendarahan, karsinogen dan kerusakan otak (EhiEromosele, 2012). Air sadah $\left(\mathrm{CaCO}_{3}\right)$ dapat menyebabkan penyakit kardiovaskuler bagi manusia (Hussain et al, 2012). Logam seng (Zn) adalah logam essensial bagi tubuh akan tetapi kelebihan logam ini akan sangat berbahaya dan bersifat toksik. Tingginya kadar $\mathrm{Mn}^{+2}$, $\mathrm{Ca}^{+2}, \mathrm{Na}^{+}, \mathrm{Cl}^{-}$dan $\mathrm{SO}_{4}{ }^{-2}$ disebabkan oleh limbah yang berasal dari kegiatan domestic rumah tangga (Meybeck\& Halmer, 1996). Kelebihan ion $\mathrm{Fe}^{+2}$ dan $\mathrm{Mn}^{+2}$ dapat menyebabkan gangguan neurologis (Standard Organization of Nigeria, 2007).

Water Quality Index dihitung berdasarkan standar dari World health organization (Brown, Clelland, Dininger \&Tozer,, 1970) secara aritmatika sesuai rumusan dibawah ini :

$$
\mathrm{WQI}=\Sigma \mathrm{Qn} . \mathrm{Wn} / \Sigma \mathrm{Wn}
$$

Dimana

$$
\begin{aligned}
& \text { WQI = Water Quality Index } \\
& \text { Qn } \quad \begin{array}{l}
\text { Water Quality Rating tiap } \\
\text { parameter }
\end{array} \\
& \text { Wn } \quad \text { unit berat tiap parameter }
\end{aligned}
$$

Hasil perhitungan Water Quality Index dari kelima sampel sumur dapat dilihat pada tabel 3 dibawah ini

Tabel 3. Hasil WQI

\begin{tabular}{|c|c|c|}
\hline Sampel & WQI & Kesimpulan \\
\hline Sumur A & 45,66811 & excellent \\
\hline Sumur B & 45,42535 & excellent \\
\hline Sumur C & 45,84581 & excellent \\
\hline Sumur D & 46,34022 & excellent \\
\hline Sumur E & 45,59327 & excellent \\
\hline
\end{tabular}

\section{KESIMPULAN}

Berdasarkan parameter fisika disimpulkan bahwa 5 sampelair sumur yang diperiksa karakteristik bau memenuhi syarat, 5 sampel air sumur yang diperiksa karakteristik rasa memenuhi syarat, 4 sampel air sumur yang diperiksa karakteristik jumlah padatan terlarut memenuhi syarat, 3 sampel kekeruhan memenuhi syarat, dan

5 sampel air sumur yang diperiksa karakteristik suhu dan warna memenuhi syarat. Berdasarkan parameter kimia disimpulkan bahwa kelima sampel tidak ada yang melebihi batas maksimal kadar yang diizinkan kecuali untuk parameter pH.Water Quality Indeks semua sampel < 50 yang menunjukkan semua sampel dalam kondisi baik.

\section{DAFTAR PUSTAKA}

Abdul, M., Jusuf, H., Prasetya, E. (2014). Uji kualitas air sumur gali di wilayah pesisir pantai (studi penelitian sumur gali di desa Bulontio Barat kecamatan Sumalata kabupaten Gorontalo Utara Provinsi Gorontalo. Fakultas Ilmu Kesehatan.Universitas Gorontalo.

Aboyeji, O.S.,\& Eigbkhan,S.F. (2016). Evaluations of groundwater containations by leachates around Ousosun Open dumpsites in Lagos metropolis, south west Nigeria. Jurnal of environment management 83. pp 333-341.

Ali, M. (2011).Monograf rembesan air lindi (Leachate) dampak pada tanaman pangan dan kesehatan. Surabaya. UPN Press.

Arbain,,Mardana, N \& Sudana, I.(2012). Pengaruh Air Lindi TPA Sampah Suwung Terhadap Kualitas Air Tanah Dangkal di Sekitarnya di Kelurahan Pedungan Kota Denpasar.Ecotrophic : Jurnal Ilmu Lingkungan, 3(2) retrieved from https://ojs.unud.ac.id/index.php/ECOTR OPHIC/article/view/2504pp. 55-60 
Bahagia, Yunita, I., Ruslin. (2018). Analisa kualitas air sumurpemukiman kumuh gampong be Urawe Kota Banda Aceh. Serambi Enggineering, Volume III Edisi khusus Februari 2018. pp 285-291.

Biswas, A.K., Kumar, S., Satheesh, S., Bhattacharyya, J.K., Chakra berti, T. (2010). Studies on environmental quality in and around municipal solid dumpsite.Resources, Conservation and recycling 55(2010). pp 129-134

Brown, R.M., Clelland, M.C;Dininger R.A; Tozer, R.G. (1970). Water Quality Indeks. Do we dare ?. Water and sewage work. 117. pp 339-343

Chwodhury, S., Mazumder, A., Al Attas, A., Husain, T. (2016). Heavy metals in drinking water ; oocurences, implication and future needs in developing countreis. Science of total environment. pp 476-488

Eddy, N.O.,\&Ekop, A.S.(2007). Assessment of quality of water treated and distributed by AkwaIbon State Company. E-J Chem. Vol 4(2). pp180-186.

Ehi-Eromosele, Okiei W. (2012). Resources and Environment. Vol 2(3). pp 82-86

Hussain .(2012). Journal of agriculture and envirenmental science. 12(8). pp 1091-1094.

Ignatius, N.K., Thara, K., Dheenadayalan,M.S. (2018). Phsycochemical study of groundwater quality at selected locations in periyakulum theni district. Tamilnadu. India. Material Today Proceedings 5.pp 422-428.

Ikem, A., Osibanju,O., Sidhan.,M.K.C., sobande, A. (2002). Evaluation of groundwter quality characteristic near two waste sites in Ibea and Lagos, Nigeria.Water, Air, and Soil Pollution 140. pp 307-333

Indah, A.Y.,Hilda Zulkifli, M. Faisal. (2006). Pengaruh lindi TPA sampah batu putih kabupaten OKU terhadap Kualitas Air disekitar TPA.Jurnal pengelolaan Lingkungan 4 (2). pp 37-46

Gofur, A., Kartini, A.D., Rahman. (2016). Studi Kualitas Fisika, Kimia dan Biologi pada air minum dalam kemasan berbagai merek yang beredar di Kota Makassar tahun 2016.Universitas

Muslim

Indonesia.Makassar.

Gusnisar, .(2012). Pengaruh sumur resapan terhadap kualitas air tanah. Skripsi.Fakultas teknik.Universitas Indonesia.

Marwati, N, Mardani, N., \& Sundra, I. (2012). Kualitas air sumur ditinjau dari kondisi lingkungan fisik dan perilaku masyarakat di wilayah puskesmas I Denpasar Selatan.ECOTROPHIC : Jurnal Ilmu Lingkungan (Journal of environmental science), 5(1) Retrieved from https://ojs.unud.ac.id/index.php/EC OTROPHIC/article/view/2512 . pp 63-69

Meybeck, M., Helmer, R. (1996). Introduction in: D. Chapman [Ed]. Water quality Assessments.A guideto use biota, sediments and water environmental monitoring. $2^{\text {nd }}$ edition.Chapman and Hall. London

Mukti, A.M. (2008). Penggunaan tanaman Eceng Gondok (Eichorniacrassipes) sebagai pretreatment pengolahan Air Minum pada air selokan Mataram. Laporan 
Tugas Akhir. Jogjakarta. Universitas Islam Indonesia

Narsi, Wahyuni, R.R, \&Susanti, Y. (2017).Uji Kelayakan air minum isi ulang di pasir pengaraian kabupaten rokan hulu Riau.Jurnal Ilmu Pangan dan Hasilpertanian. Volume 1 No 1. pp 11-21.

Nas, B. (2009).Geostatistical approach to assessment of spatial distribution of ground water quality.Journal of environmental sanitation. Vol 1(4).pp 163-172

Nayyef, M.A.,\&Amal, A.S. (2012). Efficiency of Lemma minor $\mathrm{L}$ in the Phytoremediation of waste water pollutans from basrah oil refinery. Journal of Applied Biotechnology in environmental sanitation.1(4). pp 163-172

Parera, M.J., Wenny, S., \&Jimmy, F.R(2012). Analisis perbedaan pada uji kualitas air sumur di kelurahan Madidir Ure kota Bitung berdasarkan parameter fisika. Jurnal e-Biomedik (eBM).Volume 1, No 1. pp 466-472

Permenkes RI No. 492 (2010). Persyaratan kualitas air minum. Menteri Kesehatan Republik Indonesia.

Sari, G.M., Munawar, Napoleoin, A. (2015). Kualitas air di sekitar Eks tempat pembuanga akhir karya jaya Palembang. Bioscientiae Vol 12 no 1 pp $90-101$

Slamet, S.J. (2005). Toksikologi Lingkungan.Gajah Mada University Press. Yogyakarta.

Soemirat, (2009).Kesehatan Lingkungan Yogyakarta. Gadjah Mada university press.

Standard Organization of Nigeria.(2007). Nigeria Standart for drinking water
Quality Abuja, Nigeria.Price groupD Printing press

Sudadi, P. (2003). Penentuan Kualitas Air Tanah Melalui Analisis Unsur Kimia Terpilih.Direktorat Pendayagunaan Air Tanah DTLGP. Bandung.

Suripin.(2001). Pelestarian Sumber Daya Tanah dan Air. Penerbit Andi. Yogyakarta.

Suryana, W. (2013). Analisis kualitas air sumur dangkal di kecamatan Biringkanayya kota Makasar.Skripsi. Jurusan Sipil Fakultas Teknik Universitas Hasanuddin.

Trisnawulan, I., Budiarsa Suyasa, I., \& Sundra, I. (2007). Analisis kualitasair sumur gali di kawasan pariwisata sanur..ECOTROPHIC : Jurnal Ilmu Lingkungan (Journal of environment science) Volume 2 No 1 Nov 2012. pp 1-9

SNI 06-2412-1991. Metode pengambilan contoh kualitas air. Badan Standardisasi Nasional

Udhayakumar, R., Manivannan, P., Raghu, K., Vaideki, S. (2016). Assesment of physico-chemical characteristic of water in tamil nadu. Ecotoxicology and environment safety. Volume 134 part 2.pp 474477

Ugya, AY; Umar, SA; Yusuf, AS. 2015. Assessment of well water quality: A case Study of Kaduna South Local Government Area, Kaduna State Nigeria. Merit Research Journals. Vol 3(3).pp 039-043

Warsinah., Suheryanto,. Windusari, Y. (2015). Kajian cemaran logam berat timbal $(\mathrm{Pb})$ pada kompartemen di sekitar pembuangan akhir (TPA) sukawinatan Palembang.Jurnal 
penelitian sains volume 17 No 2. pp 78-81

Wardhana, W.A. (2004). Dampak pencemaran

lingkungan. Yogyakarta.Penerbit ANDI

Widana, E., et al, 2014. Uji Kualitas Air .Fakultas Sains danTeknologi. Universitas Islam Negeri Malang

Yudhyarto, B., Utomo, B., Sulastro, S. (2015). Pengaruh tempat pembuangan akhir sampah putri cempo Surakarta terhadap kualitas air tanah dangkal penduduk di sekitar. $E$ jurnal matriks teknik sipil.Volume 3 No 2. pp 564-569 